\title{
THE EFFECT OF MIXING SODIUM HYPOCHLORITE ON COMPRESSIVE STRENGTH OF TYPE III GYPSUM PRODUCT
}

\author{
Rezy Kurnia ${ }^{1}$ Hidayati $^{2}$ \\ ${ }^{1}$ Faculty of Dentistry Andalas University \\ ${ }^{2}$ Department of Dental Material Faculty of Dentistry Andalas University
}

\begin{abstract}
Disinfection is needed to avoid transmission of infectious agents. One of disinfectant solution used is sodium hypochlorite. Disinfection should be done without changing the quality of gypsum models, so the technique of mixing a disinfectant solution on gypsum powder can be used as an alternative. The purpose of this study was to determined the effect of mixing sodium hypochlorite to the compressive strength of type III gypsum product. The study was conducted at the Laboratory of Materials and Structures, Faculty of Engineering, Andalas University using laboratory experimental method with 30 pieces of type III gypsum models as samples. Samples were divided into 5 groups, that were mixed using $0.5 \%$ sodium hypochlorite, $1 \%$ sodium hypochlorite, $2 \%$ sodium hypochlorite, $5 \%$ sodium hypochlorite and distilled water as a control group. Measurement of the compressive strength was performed with a Universal Testing Machine (UTM). The results showed that the models were mixed with $0.5 \%$ sodium hypochlorite, $1 \%$ sodium hypochlorite, $2 \%$ sodium hypochlorite and 5\% sodium hypochlorite reduced the average of the compressive strength compared to the models that are mixed with distilled water. One Way ANOVA test showed that was significantly differences $(p<0.05)$ among groups of $0.5 \%$ sodium hypochlorite, $1 \%$ sodium hypochlorite, $2 \%$ sodium hypochlorite, 5\% sodium hypochlorite and distilled water as a control group. It was concluded that there were effect of mixing sodium hypochlorite to reduced the compressive strength of type III gypsum product.
\end{abstract}

Keywords: type III gypsum, compressive strength, sodium hypochlorite

Affiliasi Penulis : ${ }^{1}$ Faculty of Dentistry Andalas University

Korespondensi : Rezy Kurnia

Email: rezykurnia@rocketmail.com

\section{PENDAHULUAN}

Gipsum tipe III merupakan salah satu bahan tuang yang digunakan dalam kedokteran gigi untuk membuat model dari rongga mulut serta struktur maksilofasial dan sebagai piranti penting dalam pembuatan protesa di laboratorium kedokteran gigi ${ }^{1}$. Menurut spesifikasi American Dental Association (ADA) No. 25, gipsum dapat diklasifikasikan menjadi tipe I (Impression plaster), tipe II (Model plaster), tipe III (Dental stone), tipe IV (Dental stone, high strength), dan tipe V (High strength, high expansion dental stone). Semua tipe gipsum yang digunakan dalam kedokteran gigi memiliki senyawa dasar yang sama, yaitu kalsium sulfat hemihidrat atau CaSO $4 .{ }^{1} /{ }_{2} \mathrm{H}_{2} \mathrm{O}^{2}$.

Praktik kedokteran gigi sangat sering menggunakan produk gipsum untuk membuat model studi dan model kerja ${ }^{3}$. Pembuatan model kerja umumnya menggunakan gipsum tipe III yang memiliki kekuatan dan ketahanan abrasi lebih tinggi dibandingkan gipsum tipe II dan lebih rendah dibandingkan gipsum tipe IV dan tipe $V^{2}$. Gipsum tipe III 
mudah diperoleh dan relatif lebih murah daripada gipsum tipe IV dan tipe V.

Pembuatan model gipsum dilakukan dengan menuangkan adonan gipsum ke dalam cetakan rongga mulut dan dibiarkan mengeras ${ }^{4}$. Cetakan rongga mulut dibuat menggunakan bahan cetak yang berkontak langsung dengan mukosa mulut, saliva dan darah, sehingga berperan sebagai media transmisi mikroorganisme bagi dokter gigi ${ }^{5}$. Pembilasan sederhana bahan cetak yang terkontaminasi darah dan saliva tidak dapat mendesinfeksi mikroorganisme sehingga menyebabkan berpindahnya agen infeksi dari darah dan saliva ke model gipsum yang memudahkan kontaminasi silang antara pasien dan dokter gigi ${ }^{5,6,7}$. Mahboobi et al., 2010 dan Marya et al., 2011 mendapatkan prevalensi dokter gigi terinfeksi hepatitis B tiga sampai enam kali lebih besar dibandingkan dengan tenaga kesehatan $\operatorname{lain}^{8,9}$. Dokter gigi juga beresiko tertular berbagai penyakit mulai dari influensa hingga tuberkulosis, hepatitis dan AIDS sehingga tindakan desinfeksi dibutuhkan untuk mencegah penyebaran agen infeksi $\mathrm{ini}^{5,7}$.

Metode desinfeksi yang direkomendasikan ADA dan Centers for Disease Control and Prevention untuk mencegah penyebaran mikroorganisme dengan melakukan desinfeksi pada bahan cetak dan model gipsum. Teknik ini dapat berupa teknik penyemprotan, perendaman atau pencampuran bahan dengan larutan desinfektan ${ }^{10}$.

Zarakani et al menyatakan teknik desinfeksi bahan cetak dengan penyemprotan maupun perendaman menyebabkan perubahan stabilitas dimensi bahan cetak yang akan mempengaruhi hasil akhir model gipsum $^{5}$. Desinfeksi model gipsum dengan teknik penyemprotan tidak dapat mencakup seluruh permukaan ${ }^{10}$. Model gipsum didesinfeksi dengan teknik perendaman mengakibatkan melarutnya gipsum dan merubah dimensi model ${ }^{7}$.

Desinfeksi sebaiknya dilakukan tanpa menyebabkan perubahan pada kualitas model gipsum, sehingga teknik pencampuran larutan desinfektan dapat dijadikan alternatif $^{11,12,13}$. Larutan desinfektan yang digunakan juga harus dapat membunuh agen infeksi tanpa menurunkan kualitas model gipsum ${ }^{10}$.

Natrium hipoklorit $(\mathrm{NaOCl})$ merupakan salah satu bahan desinfektan yang murah, mudah diperoleh sehingga sering digunakan karena dapat membunuh virus hepatitis, HIV, SARS, serta bakteri positif Gram dan negatif Gram ${ }^{7}$. American Dental Association merekomendasikan konsentrasi larutan 
natrium hipoklorit yang berperan sebagai desinfektan, yaitu $0,5 \%, 1 \%, 2 \%, 5 \%$, dan $5,25 \%^{14}$.

Penelitian Memarian et al., 2007 menunjukkan natrium hipoklorit $0,5 \%$ sudah dapat menghambat pertumbuhan mikroorganisme pada bahan cetak yang direndam selama 10 menit. Penggunaan konsentrasi natrium hipoklorit tergantung pada jenis mikroorganisme ${ }^{15}$. Natrium hipoklorit 5,25\% merupakan desinfektan spectrum luas dengan aksi cepat dalam waktu 1 menit $^{16}$.

Model gipsum harus memiliki kekuatan tekan tinggi serta resisten terhadap fraktur dan abrasi ${ }^{17}$. Kekuatan tekan dinyatakan dalam satuan megapascals (MPa) yang dikalkulasikan dari kegagalan sampel dalam menahan beban dibagi dengan luas penampang sampel $^{18}$. Kekuatan tekan gipsum tipe III adalah 20,7-34,5 $\mathrm{MPa}^{1}$.

Beberapa penelitian telah mengevaluasi efek pencampuran desinfektan pada bubuk gipsum. Pencampuran natrium hipoklorit $0,5 \%$ saat pengadukan gipsum dilaporkan terjadinya peningkatan kekuatan tekan model gipsum tipe III dibandingkan tanpa pencampuran ${ }^{5}$. Penelitian Abedelaziz et al (2002) dilaporkan penurunan kekuatan tekan pada gipsum tipe III dan tipe IV $^{19}$. Pencampuran natrium hipoklorit $1 \%$ pada gipsum tipe IV menunjukkan penurunan kekuatan tekan dibandingkan dengan pencampuran natrium hipoklorit 0,5\% dan tanpa pencampuran ${ }^{20}$. Breault et al juga melakukan pencampuran larutan natrium hipoklorit 5,25\% pada gipsum tipe $\mathrm{V}$ dan menghasilkan peningkatan kekuatan tekan ${ }^{14}$. Pencampuran Natrium hipoklorit juga memengaruhi sifat-sifat lain, seperti penurunan waktu pengerasan dan detail permukaan ${ }^{5,14}$

Banyak penelitian yang telah menguji pengaruh larutan natrium hipoklorit terhadap kekuatan tekan gipsum. Namun, penelitian yang dilakukan hanya menggunakan satu atau dua jenis konsentrasi larutan. Sejauh yang penulis ketahui, belum ada penelitian tentang pengaruh pencampuran natrium hipoklorit dengan konsentrasi $0,5 \%, 1 \%, 2 \%$ dan $5 \%$ terhadap kekuatan tekan gipsum tipe III. Penelitian ini bertujuan untuk mengetahui pengaruh pencampuran natrium hipoklorit terhadap kekuatan tekan gipsum tipe III

\section{METODE PENELITIAN}

Penelitian yang digunakan adalah eksperimental laboratoris dengan post test only control group design. Penelitian dilaksanakan di Ruang Skills Lab Fakultas Kedokteran Gigi dan Laboratorium Material dan Struktur Jurusan Teknik Sipil Fakultas Teknik 
Universitas Andalas pada bulan FebruariApril 2016. Sampel penelitian adalah model tabung gipsum tipe III yang memenuhi kriteria inklusi dan eksklusi yang berjumlah 30 sampel berbentuk tabung (6 sampel dalam tiap kelompok). Tiap sampel dilakukan uji kekuatan tekan dengan alat uji kekuatan tekan.

\section{HASIL PENELITIAN}

Penelitian ini merupakan penelitian eksperimental mengenai pengaruh pencampuran natrium hipoklorit terhadap kekuatan tekan gipsum tipe III. Pembuatan sampel dilakukan di ruang Skills Lab Fakultas Kedokteran Gigi pada 16 Maret 2016 dan pengujian sampel dilakukan di Laboratorium Material dan Struktur Jurusan Teknik Sipil Fakultas Teknik Universitas Andalas pada 17
Maret 2016. Sampel dalam penelitian ini adalah model gipsum tipe III berbentuk tabung dengan diameter $20 \mathrm{~mm}$ dan tinggi $40 \mathrm{~mm}$. Pada penelitian ini terdapat lima kelompok perlakuan dengan besar sampel 6 buah untuk tiap kelompok. Pengujian kekuatan tekan sampel menggunakan alat Universal Testing Machine dan dibantu oleh asisten Laboratorium Material dan Struktur Jurusan Teknik Sipil.

Data yang diperoleh dianalisis menggunakan uji One Way ANOVA karena jenis data yang akan dihubungkan adalah data numerik dengan data kategorik yang lebih dari dua kelompok. Sebelumnya dilakukan uji normalitas menggunakan Saphiro Wilk untuk mengetahui distribusi data.

Tabel 1 Hasil Uji One Way ANOVA Rata-Rata Kekuatan Tekan Gipsum Tipe III Berdasarkan Konsentrasi Natrium Hipoklorit

\begin{tabular}{lcccc}
\hline \multicolumn{1}{c}{ Kelompok } & n & Mean (MPa) & Standar & Nilai p \\
Deviasi & \\
1 (Kontrol) & 6 & 25.90 & 4.4891 & 0.006 \\
2 (Natrium hipollorit 0.5\%) & 6 & 22.24 & 2.9109 & \\
3 (Natrium hipollorit 1\%) & 6 & 21.12 & 3.6638 & \\
4 (Natrium hipollorit 2\%) & 6 & 19.99 & 1.9757 & \\
5 (Natrium hipollorit 5\%) & 6 & 18.02 & 3.1466 &
\end{tabular}

Berdasarkan hasil uji normalitas menggunakan Saphiro Wilk menunjukkan bahwa data terdistribusi normal karena nilai $\mathrm{p}>0.05$, yaitu $\mathrm{p}=0.063$. Selanjutnya dilakukan uji statistik menggunakan One
Way ANOVA dengan tingkat signifikan $\mathrm{p}<0.05$.

Tabel 1 menunjukkan bahwa ratarata kekuatan tekan gipsum tipe III mengalami penurunan bila konsentrasi 
natrium hipoklorit ditingkatkan. Pada uji

One Way ANOVA didapatkan nilai $\mathrm{p}=0.006$. Hal menunjukkan adanya perbedaan signifikan $(\mathrm{p}<0.05)$ antara kelompok kontrol, pencampuran natrium hipoklorit $0,5 \%$, pencampuran natrium hipoklorit $1 \%$, pencampuran natrium hipoklorit $2 \%$, dan pencampuran natrium hipoklorit 5\%. Untuk mengetahui perbedaan rata-rata kekuatan tekan antar kelompok sampel dilakukan dengan uji Least Significant Difference (LSD) test.

Tabel 2 Hasil Uji Least Significant Difference ( $L S D)$ Berdasarkan Konsentrasi Natrium Hipoklorit

\begin{tabular}{lc}
\hline \multicolumn{1}{c}{ Kelompol } & $\mathrm{p}$ \\
Kontrol dengan natrium hipollorit $0.5 \%$ & 0.069 \\
Kontrol dengan natrium hipollorit $1 \%$ & $0.020^{*}$ \\
Kontrol dengan natrium hipollorit $2 \%$ & $0.005^{*}$ \\
Kontrol dengan natrium hipollorit $5 \%$ & $0.000^{*}$ \\
\hline "Nilai p=0.05
\end{tabular}

Berdasarkan tabel 2, hasil analisis LSD dapat disimpulkan bahwa tidak terdapat perbedaan signifikan bila kelompok kontrol dibandingkan dengan kelompok natrium hipoklorit $0.5 \%$. Perbedaan signifikan $(\mathrm{p}<0.05)$ terlihat pada kelompok kontrol yang dibandingkan dengan kelompok natrium hipoklorit 1\%, kelompok natrium hipoklorit $2 \%$, dan kelompok natrium hipoklorit $5 \%$.

Berdasarkan uraian di atas terdapat perbedaan signifikan kekuatan tekan gipsum tipe III bila kelompok kontrol dibandingkan dengan pencampuran natrium hipoklorit 1\%, 2\% dan 5\%. Hal ini berarti bahwa kekuatan tekan gipsum tipe III menunjukkan perbedaan signifikan dengan peningkatan konsentrasi natrium hipoklorit.

\section{PEMBAHASAN}

Penelitian ini dilakukan untuk mengetahui pengaruh pencampuran natrium hipoklorit terhadap kekuatan tekan gipsum tipe III. Sampel yang digunakan dalam penelitian ini berjumlah 30 buah dengan pengulangan 6 buah untuk tiap kelompok. Sampel dibuat dari gipsum tipe III yang dicampurkan dengan akuades dan larutan natrium hipoklorit $0,5 \%, 1 \%, 2 \%$, dan 5\%. Penentuan konsentrasi tersebut berdasarkan rekomendasi ADA tentang konsentrasi natrium hipoklorit yang dapat berperan sebagai desinfektan.

Sampel merupakan model gipsum tipe III yang dibuat dalam bentuk tabung 
dengan diameter $20 \mathrm{~mm}$ dan tinggi 40 mm. Pembuatan sampel diawali dengan menakar air dan bubuk gipsum, pengadukan, dan penuangan ke dalam cetakan berbentuk tabung. Rasio air dan bubuk yang digunakan adalah 0,3. Pengadukan dilakukan secara manual menggunakan spatula dengan gerakan sirkuler selama 1 menit dengan kecepatan 120 rpm. Hasil adukan gipsum kemudian dituangkan ke dalam cetakan yang dialas dengan kaca dan diletakkan di atas vibrator yang menyala. Sampel dibiarkan mengeras selama 45 menit, kemudian dikeluarkan dari cetakan. Pengujian kekuatan tekan sampel dilakukan setelah sampel dibiarkan kering selama 24 jam setelah pengadukan. Sampel diuji menggunakan alat Universal Testing Machine (UTM).

Berdasarkan penelitian yang telah dilakukan, diketahui bahwa peningkatan konsentrasi larutan natrium hipoklorit menyebabkan penurunan kekuatan tekan gipsum tipe III. Pada tabel 1 menunjukkan bahwa rata-rata kekuatan tekan gipsum tipe III pada kelompok kontrol adalah sebesar $25.90 \mathrm{MPa}$, pencampuran natrium hipoklorit $0,5 \%$ sebesar 22.24 $\mathrm{MPa}$, pencampuran natrium hipoklorit $1 \%$ sebesar 21.12 $\mathrm{MPa}$, pencampuran natrium hipoklorit $2 \%$ sebesar $19.99 \mathrm{MPa}$, dan pencampuran natrium hipoklorit $5 \%$ sebesar 18.02 MPa. Hal ini dapat disebabkan oleh kandungan natrium pada natrium hipoklorit yang bersifat higroskopis, sehingga menarik air dan menyebabkan penurunan kekuatan tekan pada model.

Berdasarkan hasil penelitian yang dilakukan, terlihat pengaruh pencampuran natrium hipoklorit terhadap kekuatan tekan gipsum tipe III. Hasil uji One Way ANOVA menunjukkan adanya perbedaan yang signifikan antar kelompok dengan nilai $\mathrm{p}<0.05$, yaitu 0.006

Perbedaan antar kelompok dapat diketahui dengan uji Least Significant Difference. Hasilnya menunjukkan bahwa kelompok natrium hipoklorit $0,5 \%$ tidak memiliki perbedaan kekuatan tekan yang signifikan dibandingkan dengan kelompok kontrol dan merupakan desinfektan dengan sifat toksik terendah yang dapat digunakan untuk mendesinfeksi model gipsum tipe III

Salah satu kandungan dalam larutan natrium hipoklorit adalah natrium klorida (NaCl). Menurut Christine (2012), penambahan natrium klorida dapat menurunkan kekuatan tekan gipsum dalam nilai yang masih dapat diterima secara klinis sesuai dengan standar American Dental Association No. 25. Bahan kimia ini menempati ruang 
interkristalin, sehingga dapat menurunkan kohesi interkristalin dan menghasilkan jalinan interkristalin yang buruk. Hal ini mengakibatkan berkurangnya kekuatan tekan pada gipsum.

Penelitian Mohammad et al (2014) tentang efek pencampuran desinfektan terhadap kekuatan tekan gipsum tipe IV, salah satunya menggunakan natrium hipoklorit. Konsentrasi natrium hipoklorit yang digunakan adalah $0,5 \%$ dan $1 \%$. Hasil penelitian tersebut menunjukkan pencampuran natrium hipoklorit $1 \%$ menghasilkan kekuatan tekan yang lebih rendah dibandingkan natrium hipoklorit $0,5 \%$ dan tanpa pencampuran. Terlihat dari hasil penelitian tersebut bahwa semakin besar konsentrasi natrium hipoklorit, maka kekuatan tekan yang dihasilkan semakin kecil.

Pada dasarnya, penurunan kekuatan tekan disebabkan oleh pencampuran natrium hipoklorit yang menghasilkan suatu garam lemah, seperti natrium klorida. Natrium hipoklorit dalam konsentrasi tinggi dapat mengakibatkan garam ini melampaui batas kelarutan, sehingga akan mempengaruhi kristalisasi dan sifat gipsum. Penelitian Mohammad et al (2014) menyimpulkan bahwa natrium hipoklorit dalam konsentrasi rendah tidak menunjukkan penurunan kekuatan tekan gipsum tipe IV yang signifikan dalam 24 hingga 48 jam pengeringan.

Hasil penelitian ini mendukung penelitian Abdelaziz et al (2002) yang membuktikan bahwa peningkatan konsentrasi natrium hipoklorit menunjukkan penurunan kekuatan tekan pada gipsum tipe III dan tipe IV. Hal ini disebabkan adanya peningkatan porositas pada model, sehingga memungkinkan dihasilkannya suatu model yang lemah.

Bila dibandingkan dengan penelitian sejenis yang dilakukan, terdapat perbedaan hasil yang diperoleh. Hasil yang diperoleh dalam penelitian Zarakani et al (2014), pencampuran natrium hipoklorit $\quad 0,5 \%$ menunjukkan peningkatan kekuatan tekan gipsum tipe III dibandingkan dengan tanpa pencampuran. Secara umum, perbedaan perolehan hasil mungkin disebabkan karena perbedaan merek natrium hipoklorit dan gipsum yang digunakan.

Natrium hipoklorit $0,5 \%$ dan $1 \%$ dapat digunakan untuk mendesinfeksi model gipsum tipe III, sehingga diperoleh model yang bebas dari agen infeksi dan memiliki nilai kekuatan tekan yang masih dapat diterima secara klinis sesuai dengan standar American Dental Association. Keterbatasan penelitian ini yaitu pengadukan gipsum yang dilakukan 
secara manual, sehingga kekuatan dan

kecepatan pengadukan pada tiap sampel dapat berbeda.

\section{KESIMPULAN}

Pada penelitian ini dapat diambil kesimpulan bahwa pencampuran natrium hipoklorit $0,5 \%, 1 \%, 2 \%$ dan $5 \%$ memiliki pengaruh terhadap penurunan kekuatan tekan gipsum tipe III.

\section{KEPUSTAKAAN}

1. Anusavice, K.J., 2004. Phillips Buku Ajar Ilmu Bahan Kedokteran Gigi. Ed. 10. Alih Bahasa Budiman J, Purwoko S. Jakarta: EGC

2. Hatrick CD, Eakle WS, Bird WF (2003). Dental Materials: Clinical Applications for Dental Assistants and Dental Hygienists. USA: Saunders Elsevier Inc. H 230-248

3. Power JM, Wataha JC (2008). Dental Materials: Properties and Manipulation. $9^{\text {th }} e d$. St. Louis: Elsevier Inc.

4. Sakaguchi RL, Power JM (2012). Craig's Restorative Dental Materials. $13^{\text {th }} e d$. Philadelphia : Elsevier Inc. H 300-309.

5. Zarakani H, Karimi N, Sadriya S, Fayaz A., 2013. Comparison of Setting Time, Setting Expansion and Compressive Strength of Gypsum Casts Produced by Mixing Gypsum Powder with Distilled Water or $0,5 \%$ Sodium Hypochlorite. Journal of Dental School. H 162-169

6. Anaraki, M.R., Moslehifard, E., Aminifar, S. and Ghanati, H., 2013. Effect of Microwave Disinfection on Compressive and Tensile Strengths of Dental Stones. Journal of Dental Research, Dental Clinics, Dental Prospects, 7(1), H 42.

7. Moslehifard, E., Nasirpouri, F. and Gasemzadeh, S., 2013. Effect of Disinfectants on the Hardness of Dental Stones. Journal of Islamic Dental Association of IRAN (JIDAI), 25(2), H 2.
8. Mahboobi, N., Agha-Hosseini, F., Safari, S., Lavanchy, D. and Alavian, S.M., 2010. Hepatitis B Virus Infection in Dentistry: A Forgotten Topic. Journal of viral hepatitis, 17(5), H 307-316.

9. Marya, C.M., Shukla, P., Dahiya, V. and Jnaneswar, A., 2011. Current Status of Disinfection of Dental Impressions in Indian Dental Colleges: A Cause of Concern. The Journal of Infection in Developing Countries, 5(11), H 776-780.

10. Al-khafaji, A.M., Abass, S.M. and Khalaf, B.S., 2013. The Effect of SOLO and Sodium Hypochlorite Disinfectant on Some Properties of Different Types of Dental Stone. Journal of Baghdad College of Dentistry, 25(2), H 8-17.

11. Lucas, M.G., Arioli-Filho, J.N., Nogueira, S.S., Batista, A.U.D. and Pereira, R.D.P., 2009. Effect of Incorporation of Disinfectant Solutions on Setting Time, Linear Dimensional Stability, and Detail Reproduction in Dental Stone Casts. Journal of Prosthodontics, 18(6), H 521526.

12. Khalaf, H.A.R. and Mohammed, M.R., 2014. Effect of Disinfectant Agents on Certain Physical and Mechanical Properties of Type IV Dental Stone. Journal of Baghdad College of Dentistry, 26(1), H 24-31.

13. Sabouhi, M., Khodaeian, N., Ataei, E. and Kiani, F., 2014. The effect of addition of calcium hypochlorite disinfectant on setting expansion and surface hardness of dental stone. Journal of Islamic Dental Association of Iran, 26(1), H 29-34.

14. Mohan, T.K., Sandeep, C., Gopinadh, A., Manne, P. and Dev, J.R.R., 2012. An Evaluation Of The Effect Of Mixing Disinfectant Solutions On Physical Properties Of Die Stone Material-An In Vitro Study. Indian Journal of Dental Sciences, 4(5).

15. Memarian, M., Fazeli, M.R., Jamalifar, H., Azimnejad, A., 2007. Disinfection Efficiency of Irreversible Hydrocolloid Impressions Using Different Concentrations of Sodium Hypochlorite: A 
Pilot Study. The Journal of Contemporary Dental Practice, 8(4)

16. Doddamani, S., Patil, R.A., Gangadhar, S.A,. 2011. Efficacy of various spray disinfectants on irreversible hydrocolloid impression materials: An in vitro study. Indian Journal of Dental Research, 22(6), H 764-769.

17. Hasan, R.H. and Mohammad, K.A., 2013. The Effects of Drying Techniques on The Compressive Strength of Gypsum Products. Al-Rafidain Dental Journal, 5(1).

18. National Ready Mixed Concrete Association (2003). CIP 35 - Testing Compressive Strength on Concrete

19. Abdelaziz K.M., Combe E.C., Hodges J.S.,2002. The Effect of Disinfectant Additives on The Properties of Dental Gypsum: 1. Mechanical Properties. Journal of Prosthodontics, 11(3), H 161167.

20. Mohammad, Q.A., Hasan, R.H. and Thiab, S.S., 2014. Effects of Different Disinfectant Additives on Compressive Strength of Dental Stone. Journal of Babylon University, 22 